\title{
Desain dan Analisis Sistem Pengkondisian Udara Berbasis Computational Fluid Dynamics (CFD) pada Kereta Ukur Sulawesi di PT. INKA (Persero)
}

\author{
Shinta Aprilia Safitri, Sarwono, dan Ridho Hantoro \\ Departemen Teknik Fisika, Fakultas Teknologi Industri, Institut Teknologi Sepuluh Nopember (ITS) \\ e-mail : shintasafitri2@gmail.com, sarwono@ep.its.ac.id
}

\begin{abstract}
Abstrak-Sistem pengkondisian udara memegang peranan penting dalam menunjang tercapainya tingkat kenyamanan termal. Kenyamanan termal dalam kereta dapat tercapai apabila penumpang mendapatkan suplai temperatur, tingkat kelembaban, maupun pergerakan udara yang ideal dari lingkungannya. Berdasarkan perhitungan yang telah dilakukan, Kereta Ukur Sulawesi membutuhkan kapasitas pendinginan minimum sebesar 106.116,13 Btu/hr atau setara dengan $31,1 \mathrm{~kW}$. Beban tersebut dapat ditangani dengan memasang 2 unit AC dengan kapasitas masing-masing sebesar $17,5 \mathrm{~kW}$. Udara dari AC menuju ke dalam kereta Ukur Sulawesi akan disalurkan lewat saluran udara yang dirancang dengan 2 bentuk, yaitu lurus dan bercabang yang masing-masing memiliki variasi sudut pengarah pada lubang keluaran udara. Analisis desain saluran udara dilakukan dengan menggunakan software berbasis CFD. Variasi sudut pengarah menyebabkan terjadinya perubahan temperatur rata-rata dalam kereta. Pada penelitian ini didapatkan hasil bahwa desain saluran udara yang paling baik untuk diterapkan pada Kereta Ukur Sulawesi adalah saluran udara bercabang dengan variasi sudut pengarah 75 derajat. Variasi tersebut menghasilkan temperatur rata-rata $7,513{ }^{\circ} \mathrm{F}$ dengan kelembapan relatif $\mathbf{7 8 , 3 \%}$.
\end{abstract}

Kata Kunci- Beban Pendinginan, CFD, Kereta Ukur Sulawesi, Sistem Pengkondisian Udara.

\section{PENDAHULUAN}

$\mathrm{B}$ ERDASARKAN SNI 03-6390-2000, pengkondisian udara diperlukan untuk mengendalikan temperatur ruangan, kelembaban relatif, kualitas serta persebaran udara [1]. Kenyamanan termal dalam kereta dapat tercapai ketika penumpang mendapatkan supply temperatur udara, tingkat kelembaban, maupun panas yang ideal dari lingkungan sekitarnya [2] Oleh sebab itu, perlu dipasang suatu sistem pengkondisian udara (Air Conditioning System) pada Kereta Ukur Sulawesi untuk menunjang tercapainya tingkat kenyamanan termal yang dibutuhkan oleh penumpang.

Sesuai dengan spesifikasi teknis kereta ukur yang dikeluarkan oleh Direktorat Jenderal Perkeretaapian Kementrian Perhubungan Republik Indonesia, pada Kereta Ukur Sulawesi akan dilengkapi dengan dua buah AC sentral [3]. Namun, penggunaan AC sentral seringkali mengakibatkan timbulnya beberapa masalah dari segi energi maupun segi ekonomi. Ditinjau dari sisi energi, sebanyak $70 \%$ dari total penggunaan energi dalam kereta api terpakai untuk memenuhi kebutuhan sistem pengkondisian udara. Sedangkan dari sisi ekonomi, penggunaan AC sentral menyebabkan peningkatan initial cost untuk biaya instalasi saluran udara maupun isolasi termal.[4]

Sebagai upaya untuk mengatasi permasalahan ters ebut, maka perlu dilakukan optimasi desain pada sistem pengkondisian udara. Perancangan desain sistem pengkondisian udara yang baik dan efektif akan menghasilkan supply udara yang lebih baik serta meminimalisir terjadinya kerugian pada saat proses pendistribusian udara.[5] Sehingga, pada studi ini akan dilakukan desain dan analisis sistem pengkondisian udara dengan menggunakan software berbasis Computational Fluid Dynamics (CFD) untuk diterapkan pada Kereta Ukur Sulawesi di PT. INKA (Persero).

\section{TEORI PENUNJANG}

\section{A. Kenyamanan Termal}

Berdasarkan SNI 03-6572-2001, terdapat beberapa faktor yang dapat mempengaruhi kenyamanan seseorang, diantaranya [6]:

- Kelembaban Udara Relatif (RH)

Kelembapan udara relatif adalah kemampuan udara untuk menerima kandungan uap air atau perbandingan antara tekanan uap terhadap tekanan jenuh air[7]. Besarnya nilai RH didapatkan dari diagram psikrometrik, yaitu pada perpotongan nilai entalpi dan temperatur bola kering. Adapun persamaan untuk mendapatkan nilai $\mathrm{h}$ yaitu [8]:

$$
h=\left(1,006 \cdot T_{d b}\right)+\left[W \cdot\left(2501+1,805 \cdot T_{d b}\right)\right]
$$

Nilai kelembapan udara relatif dikelompokkan menjadi beberapa kategori, diantaranya [9]:

a. $\mathrm{RH} \leq 40 \%$ : kurang nyaman, kulit merasa kering yang tidak wajar.

b. $50 \% \leq \mathrm{RH} \leq 80 \%$ : nyaman, kulit kering wajar.

c. $80 \%<\mathrm{RH} \leq 90 \%$ : hangat nyaman.

d. $\mathrm{RH}>90 \%$ : tidak nyaman, udara pengap (terasa berat menekan).

- $\quad$ Temperatur Udara Kering

Temperatur udara kering sangat besar pengaruhnya terhadap besar kecilnya kalor yang dilepas melalui penguapan (evaporasi) dan melalui konveksi. Daerah kenyamanan termal untuk daerah tropis dapat dibagi menjadi: 
a. sejuk nyaman, antara temperatur efektif $20,5^{\circ} \mathrm{C}-$ $22,8^{0} \mathrm{C}$.

b. nyaman optimal, antara temperatur efektif $22,8^{\circ} \mathrm{C}-$ $25,8^{0} \mathrm{C}$.

c. hangat nyaman, antara temperatur efektif $25,8^{\circ} \mathrm{C}-$ $27,1^{0} \mathrm{C}$.

- Pergerakan Udara (Kecepatan Udara)

Untuk mempertahankan kondisi nyaman, kecepatan udara yang jatuh diatas kepala tidak boleh lebih besar dari $0,5 \mathrm{~m} /$ detik dan sebaiknya lebih besar dari 0,15 $\mathrm{m} /$ detik.

- Radiasi Permukaan yang Panas

- Aktivitas Orang

\section{B. Beban Pendinginan}

Tujuan utama sistem pengkondisian udara adalah mempertahankan keadaan udara didalam ruangan dan meliputi pengaturan temperatur, kelembaban relatif, kecepatan sirkulasi udara maupun kualitas udara. Pada tahap perencanaan, perhitungan beban pendinginan yang tepat akan menjadi dasar untuk pemilihan jenis dan kapasitas peralatan pendinginan. Perhitungan beban pendinginan dilakukan dengan menggunakan metode Cooling Load Tempetarure Difference (CLTD). Metode ini seringkali digunakan untuk memperkirakan besarnya beban pendinginan yang dipengaruhi oleh tiga jenis beban panas (beban panas akibat konduksi, beban panas akibat radiasi, dan beban panas internal)[10].

- Beban Panas akibat konduksi

$$
\begin{aligned}
& Q=U \times A \times C L T D_{C} \\
& C L T D_{C}=(C L T D+L M) \times K+\left(78-t_{R}\right)+ \\
&\left(t_{0 a}-85\right)
\end{aligned}
$$

- Beban Panas akibat radiasi

$Q=A \times S C \times S H G F \times C L F$

- Beban Infiltrasi dan Ventilasi

$$
\begin{aligned}
& Q_{S}=1.1 \times C F M \times T D \\
& Q_{L}=0.68 \times C F M \times\left(W^{\prime}{ }_{O A}-W^{\prime}{ }_{i}\right)
\end{aligned}
$$

- Beban Panas Penumpang

$$
\begin{aligned}
Q_{\text {orangs }} & =q_{S} \times n \times C L F_{P} \\
Q_{\text {Orang } L} & =q_{L} \times n
\end{aligned}
$$

- Beban Panas Peralatan

$$
Q_{\text {Equipment }}=\left(q_{E q_{S}} \times C L F_{E q}\right)+q_{E q_{L}}
$$

\section{URAIAN PENELITIAN}

Langkah-langkah dalam pelaksanaan penelitian studi ini ditunjukkan pada diagram alir di bawah ini.

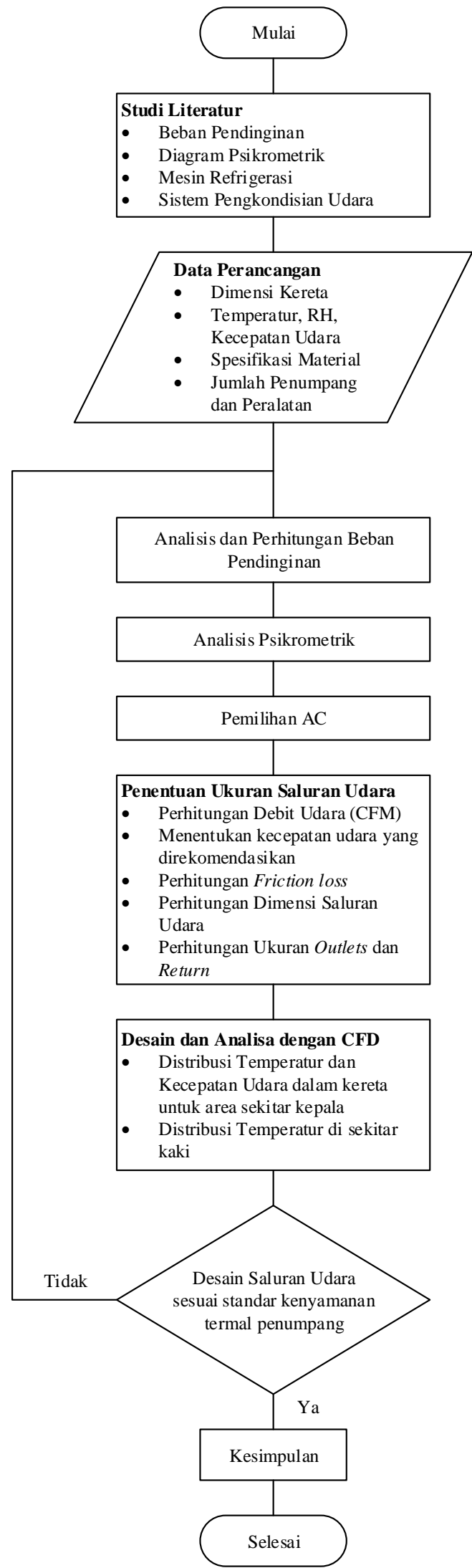

Gambar 1. Diagram Alir Studi

Dalam mencapai tujuan pada penelitian ini, dilakukan beberapa tahapan utama, yaitu perhitungan dan simulasi dengan software berbasis CFD. 


\section{A. Perhitungan Beban Pendinginan}

Perhitungan beban pendinginan pada Kereta Ukur Sulawesi mengacu pada data primer yang ditampilkan pada tabel 1 dan data sekunder yang ditampilkan pada tabel 2. Kereta Ukur Sulawesi merupakan suatu kereta yang digunakan untuk keperluan pengukuran dan pengujian prasarana penunjang kereta api yang akan dioperasikan di wilayah Sulawesi dengan rute sepanjang Makassar sampai Manado. Kereta ini memiliki dimensi sepanjang 72,18 ft dengan lebar 10,67 ft. Kereta Ukur Sulawesi mampu melaju hingga kecepatan maksimal 328084 $\mathrm{ft} / \mathrm{hr}$ atau setara dengan $100 \mathrm{~km} / \mathrm{hr}$.

Tabel 1.

Data Spesifikasi Teknis Kereta Ukur Sulawesi

\begin{tabular}{|c|c|c|c|c|}
\hline \multicolumn{5}{|c|}{ Beban Eksternal } \\
\hline \multirow{2}{*}{$\begin{array}{l}\text { Jenis } \\
\text { Beban }\end{array}$} & \multirow[b]{2}{*}{ Material } & \multicolumn{2}{|c|}{ Tebal } & \multirow{2}{*}{$\begin{array}{l}\text { Kondukti- } \\
\text { vitas }\end{array}$} \\
\hline & & $\mathrm{mm}$ & $\mathrm{ft}$ & \\
\hline \multirow{4}{*}{ Dinding } & $\begin{array}{l}\text { Corten } \\
\text { steel SPA- } \\
\text { C }\end{array}$ & 2 & 0,0065617 & 7,28 \\
\hline & GFRP & 2 & 0,0065617 & 0,021 \\
\hline & $\begin{array}{l}\text { Celah } \\
\text { udara }\end{array}$ & 20 & 0,0656168 & \\
\hline & Rock wool & 10 & 0,0328084 & 0,039 \\
\hline \multirow{4}{*}{ Atap } & $\begin{array}{l}\text { Corten } \\
\text { steel SPA- } \\
\text { C }\end{array}$ & 2 & 0,0065617 & 7,28 \\
\hline & GFRP & 2 & 0,0065617 & 0,021 \\
\hline & $\begin{array}{l}\text { Celah } \\
\text { udara }\end{array}$ & 20 & 0,0656168 & \\
\hline & Rock wool & 10 & 0,0328084 & 0,039 \\
\hline \multirow[t]{3}{*}{ Lantai } & $\begin{array}{l}\text { Corten } \\
\text { steel SPA- } \\
\text { C }\end{array}$ & 1,2 & 0,003937 & 7,28 \\
\hline & Unitex & 3,25 & 0,0106627 & \\
\hline & Lenoleum & 2,5 & 0,0082021 & \\
\hline Kaca & $\begin{array}{l}\text { Tempered } \\
\text { laminasi } \\
\text { (kegelapan } \\
60 \% \text { ) }\end{array}$ & 14,14 & 0,0463911 & \\
\hline \multicolumn{5}{|c|}{ Beban Internal } \\
\hline \multicolumn{2}{|c|}{ Jenis Beban } & Jumlah & \multicolumn{2}{|c|}{$\begin{array}{l}\text { Daya } \\
\text { (Watt) }\end{array}$} \\
\hline \multicolumn{2}{|c|}{ Penumpang } & 25 & \multicolumn{2}{|c|}{ 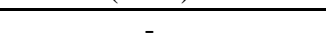 } \\
\hline \multicolumn{2}{|c|}{ Lampu Fluorescent } & 4 & \multicolumn{2}{|c|}{820} \\
\hline \multicolumn{2}{|c|}{ Dispenser } & 1 & \multicolumn{2}{|c|}{250} \\
\hline \multicolumn{2}{|c|}{ Monitor meeting room } & 6 & \multicolumn{2}{|c|}{60} \\
\hline \multicolumn{2}{|c|}{ Monitor cetv } & 1 & \multicolumn{2}{|c|}{90} \\
\hline \multicolumn{2}{|c|}{ Komputer } & 1 & \multicolumn{2}{|c|}{120} \\
\hline
\end{tabular}

Tabel 2. Data Perancangan

\begin{tabular}{lr}
\hline \hline & \multicolumn{2}{c}{ Data } \\
\hline Temperatur indoor & $75.20{ }^{\circ} \mathrm{F}$ \\
Temperatur outdoor & $92.12{ }^{\circ} \mathrm{F}$ \\
RH indoor & $50 \%$ \\
RH outdoor & $70 \%$ \\
\hline \hline
\end{tabular}

Beban pendinginan dihitung menggunakan metode Cooling Load Temperature Difference (CLTD). Metode ini seringkali digunakan untuk memperkirakan besarnya beban pendinginan yang dipengaruhi oleh tiga jenis beban panas (beban panas akibat konduksi, beban panas akibat radiasi, dan beban panas internal) [10].

Tabel 3.

Beban Pendinginan pada Kereta Ukur Sulawesi

\begin{tabular}{|c|c|c|c|c|}
\hline \multirow{2}{*}{$\begin{array}{l}\text { Space Load } \\
\text { components }\end{array}$} & \multicolumn{2}{|c|}{ Sensible Load } & \multicolumn{2}{|c|}{ Latent Load } \\
\hline & $\mathrm{Btu} / \mathrm{hr}$ & W & $\mathrm{Btu} / \mathrm{hr}$ & $\mathrm{W}$ \\
\hline $\begin{array}{l}\text { Konduksi dari } \\
\text { Atap }\end{array}$ & 7478,48 & 2191,73 & 0,00 & 0,00 \\
\hline $\begin{array}{l}\text { Konduksi dari } \\
\text { Dinding }\end{array}$ & 9877,57 & 2894,83 & 0,00 & 0,00 \\
\hline $\begin{array}{l}\text { Konduksi dari } \\
\text { Kaca }\end{array}$ & 9503,49 & 2785,20 & 0,00 & 0,00 \\
\hline $\begin{array}{l}\text { Konduksi dari } \\
\text { Lantai }\end{array}$ & 2558,82 & 749,92 & 0,00 & 0,00 \\
\hline $\begin{array}{l}\text { Radiasi Matahari } \\
\text { dari Kaca }\end{array}$ & 6388,51 & 1872,29 & 0,00 & 0,00 \\
\hline Penumpang & 5750,00 & 1685,16 & 4625,00 & 1355,45 \\
\hline Penerangan & 13940,00 & 4085,41 & 0,00 & 0,00 \\
\hline Peralatan & 2788,00 & 817,08 & 0,00 & 0,00 \\
\hline Infiltrasi & 1762,87 & 516,64 & 6174,92 & 1809,69 \\
\hline $\begin{array}{l}\text { Total Space } \\
\text { Cooling Load }\end{array}$ & 60047,74 & 17598,25 & 10799,92 & 3165,14 \\
\hline
\end{tabular}

\section{B. Perhitungan Udara Supply}

Dari perhitungan beban pendinginan yang telah dilakukan, didapatkan nilai beban-beban sebagaimana ditunjukkan oleh tabel 4. Sehingga didapatkan beban total minimal yang harus ditanggung AC untuk mengkondisikan udara di dalam Kereta Ukur Sulawesi.

Tabel 4.

Beban-Beban pada Kereta Ukur Sulawesi

\begin{tabular}{lrrrr}
\hline \hline & \multicolumn{1}{c}{ Btu/hr } & \multicolumn{1}{c}{ Kkal/hr } & \multicolumn{1}{c}{ Watts } & \multicolumn{1}{c}{ PK } \\
\hline RSHG & 60047,74 & 15141,88 & 17598,26 & 6,67 \\
RLHG & 10799,92 & 2723,35 & 3165,14 & 1,20 \\
RSHGk & 63050,13 & 15898,97 & 18478,17 & 7,01 \\
RTHG & 70847,66 & 17865,23 & 20763,40 & 7,87 \\
RTHGk & 74390,04 & 18758,49 & 21801,57 & 8,27 \\
OASH & 6979,50 & 1759,98 & 2045,49 & 0,78 \\
OALH & 24447,62 & 6164,81 & 7164,89 & 2,72 \\
OASHk & 7328,48 & 1847,98 & 2147,76 & 0,81 \\
OATHk & 31776,09 & 8012,79 & 9312,65 & 3,53 \\
GTH & $\mathbf{1 0 6 1 6 6 , 1 3}$ & $\mathbf{2 6 7 7 1 , 2 8}$ & $\mathbf{3 1 1 1 4 , 2 2}$ & $\mathbf{1 1 , 8 0}$ \\
\hline \hline
\end{tabular}

Sistem pendistribusian udara pada Kereta Ukur Sulawesi adalah pengkondisian udara dengan menggunakan mixture air sebagaimana diilustrasikan oleh gambar 2. 


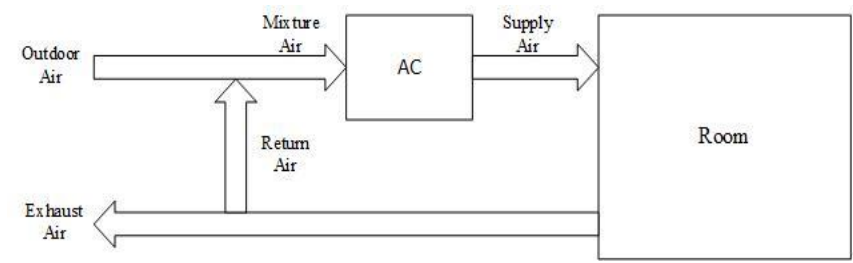

Gambar 2. Skema mixture air

Supply udara berperan penting dalam proses pendinginan ruangan. Temperatur udara suplai biasanya dapat ditentukan terlebih dahulu sehingga beda temperatur udara antara ruangan dan supply berkisar $15-30^{\circ} \mathrm{F}$. Dalam hal ini, diasumsikan beda temperatur udara sebesar $18^{\circ} \mathrm{F}$ [11]

$$
\begin{aligned}
& T_{R}-T_{S}=18^{\circ} \mathrm{F} \\
& T_{S}=75,2-18=57,2^{\circ} \mathrm{F}
\end{aligned}
$$

Sehingga besarnya debit udara supply dapat dicari dengan menggunakan persamaan:

$$
\begin{aligned}
\text { CFM }_{s} & =\frac{R S H G}{1,1 \times\left(T_{R}-T_{S}\right)} \\
& =1592,17 f t 3 / \mathrm{min} \\
& =1600 \mathrm{ft} / \mathrm{min}
\end{aligned}
$$

Debit udara tersebut adalah debit udara supply yang dibutuhkan oleh 1 AC. Jika Kereta Ukur menggunakan 2 buah AC, maka besarnya debit udara suplai yang dibutuhkan adalah:

$$
C F M_{2 S}=2 \times 1600=3200 \mathrm{ft} 3 / \mathrm{min}
$$

\section{Perhitungan Ukuran Saluran Udara}

Perancangan saluran udara dilakukan dengan menggunakan metode equal friction.

Tabel 5.

Ukuran Saluran Lurus Kereta Ukur Sulawesi

\begin{tabular}{cccccc}
\hline \hline Section & $\begin{array}{c}\text { Airflow } \\
(\mathbf{f t 3} / \mathbf{m i n})\end{array}$ & $\begin{array}{c}\text { Velocity } \\
(\mathbf{f t} / \mathbf{m i n})\end{array}$ & $\begin{array}{c}\text { Diameter } \\
\text { (in) }\end{array}$ & $\begin{array}{c}\text { Rect. } \\
\text { Size } \\
\text { (in) }\end{array}$ & $\begin{array}{c}\text { Friction } \\
\text { Loss } \\
\text { (in.w.per } \\
\mathbf{1 0 0} \mathbf{f t})\end{array}$ \\
\hline 0 & 1600 & 900 & 18,0 & $16 \times 16$ & 0,067 \\
$0-2$ & 700 & 750 & 13,2 & $9 \times 16$ & 0,067 \\
$0-3$ & 900 & 800 & 15,1 & $12 \times 16$ & 0,067 \\
$2-1$ & 400 & 650 & 10,8 & $6 \times 16$ & 0,067 \\
$3-4$ & 600 & 700 & 12,4 & $7.5 \times 16$ & 0,067 \\
$4-5$ & 300 & 600 & 9,6 & $5 \times 16$ & 0,067 \\
\hline \hline
\end{tabular}

Tabel 6.

Ukuran Saluran Bercabang Kereta Ukur Sulawesi

\begin{tabular}{cccccc}
\hline \hline Section & $\begin{array}{c}\text { Airflow } \\
(\mathbf{f t 3} / \mathbf{m i n})\end{array}$ & $\begin{array}{c}\text { Velocity } \\
(\mathbf{f t} / \mathbf{m i n})\end{array}$ & $\begin{array}{c}\text { Diameter } \\
\text { (in) }\end{array}$ & $\begin{array}{c}\text { Rect. } \\
\text { Size } \\
\text { (in) }\end{array}$ & $\begin{array}{c}\text { Friction } \\
\text { Loss } \\
\text { (in.w.per } \\
\mathbf{1 0 0} \mathbf{f t})\end{array}$ \\
\hline 0 & 1600 & 900 & 18,0 & $15 \times 18$ & 0,067 \\
$0-2$ & 320 & 600 & 9,8 & $8 \times 10$ & 0,067 \\
$2-1$ & 160 & 500 & 7,6 & $5 \times 10$ & 0,067 \\
$0-4$ & 320 & 600 & 9,8 & $8 \times 10$ & 0,067 \\
$3-4$ & 160 & 500 & 7,6 & $5 \times 10$ & 0,067 \\
$0-5$ & 480 & 680 & 12,0 & $12 \times 10$ & 0,067 \\
\hline \hline
\end{tabular}

\begin{tabular}{cccrcc}
\hline \hline $5-6$ & 320 & 600 & 9,8 & $8 \times 10$ & 0,067 \\
$6-7$ & 160 & 500 & 7,6 & $5 \times 10$ & 0,067 \\
$0-8$ & 480 & 680 & 12,0 & $12 \times 10$ & 0,067 \\
$8-9$ & 320 & 600 & 9,8 & $8 \times 10$ & 0,067 \\
$9-10$ & 160 & 500 & 7,6 & $5 \times 10$ & 0,067 \\
\hline \hline
\end{tabular}

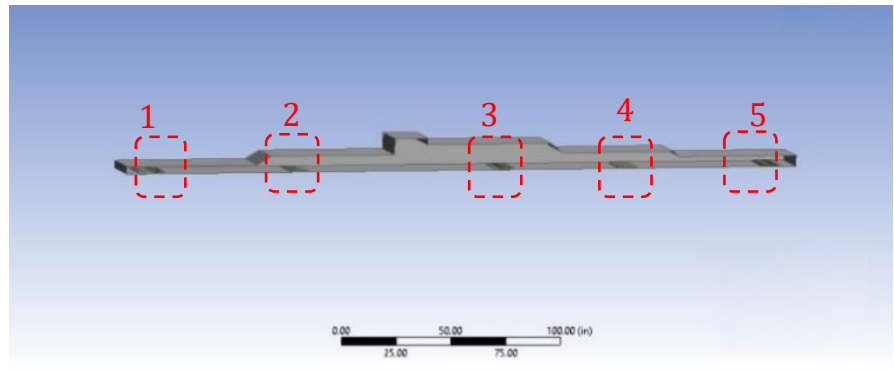

Gambar 3. Desain saluran udara lurus

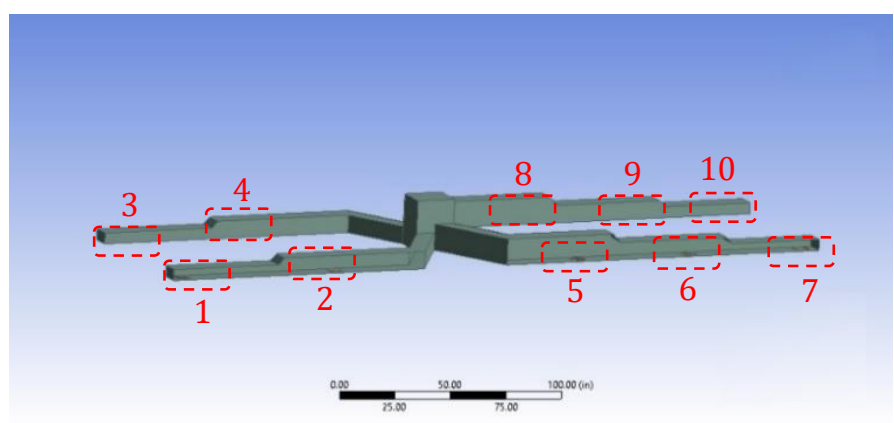

Gambar 4. Desain saluran udara bercabang

Desain saluran udara lurus memiliki 5 lubang keluaran dengan ukuran 12 inch $\mathrm{x} 12$ inch untuk lubang yang mengeluarkan debit udara $400 \mathrm{ft} 3 / \mathrm{min}$ dan ukuran 12 inch $\mathrm{x} 9$ inch untuk lubang yang mengeluarkan debit udara sebesar 300 $\mathrm{ft} 3 / \mathrm{min}$. Sedangkan saluran udara yang bercabang memiliki 10 lubang keluaran, dengan ukuran lubang udara 5 inch $\times 6$ inch untuk lubang yang mengeluarkan debit sebesar $160 \mathrm{ft} 3 / \mathrm{min}$. Pada masing-masing lubang udara dilengkapi dengan pengarah atau disebut grill dengan variasi 45 derajat, 60 derajat, 75 derajat, dan 90 derajat.

\section{HASIL DAN PEMBAHASAN}

\section{A. Distribusi Temperatur pada Kereta Ukur Sulawesi}

Dari hasil kontur temperatur, nampak bahwa distribusi temperatur dalam kereta pada saluran bercabang lebih merata jika dibandingkan dengan saluran lurus. Hal ini dikarenakan pada saluran udara bercabang udara keluar dari kedua sisi, yaitu sisi kanan dan kiri kereta, sehingga distribusinya lebih merata. Namun penggunaan saluran udara lurus lebih mampu menangani panas pada ruang masinis depan dan belakang. Pada saluran udara lurus, debit udara yang keluar pada bagian ujung saluran adalah $400 \mathrm{ft} 3 / \mathrm{min}$. Sedangkan pada saluran bercabang, masing-masing ujungnya hanya mengeluarkan debit 160 $\mathrm{ft} 3 / \mathrm{min}$. 


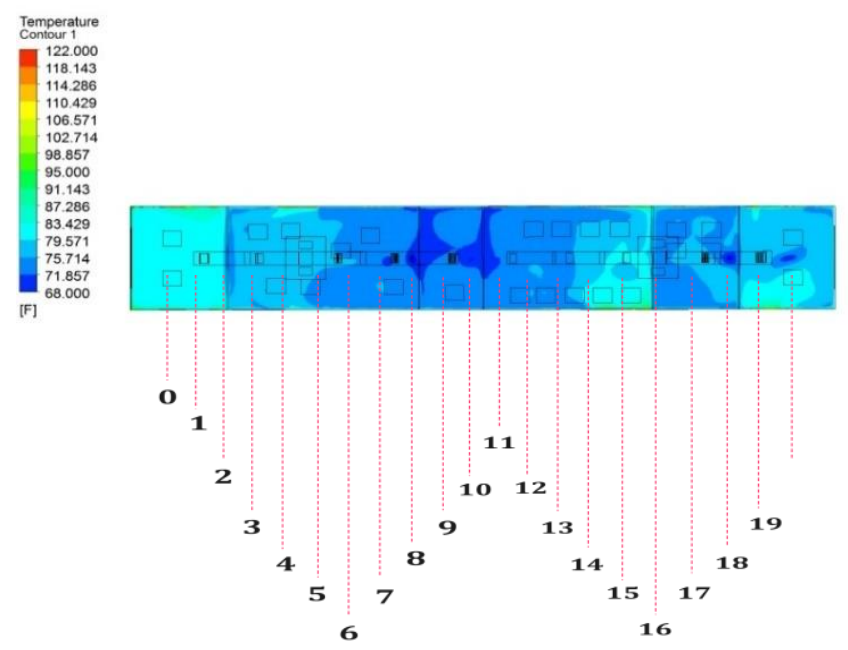

Gambar 5. Kontur distribusi temperatur saluran udara lurus dengan pengarah 75 derajat.

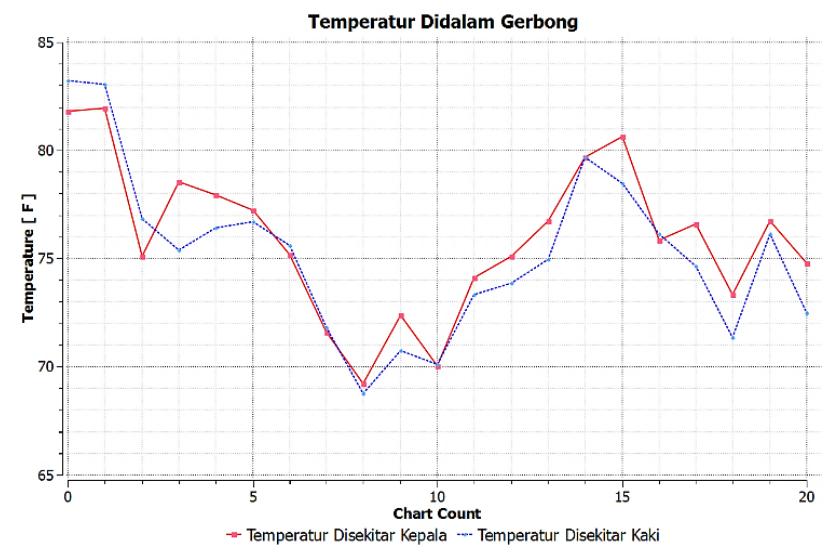

Gambar 6. Grafik distribusi temperatur saluran udara lurus dengan pengarah75 derajat

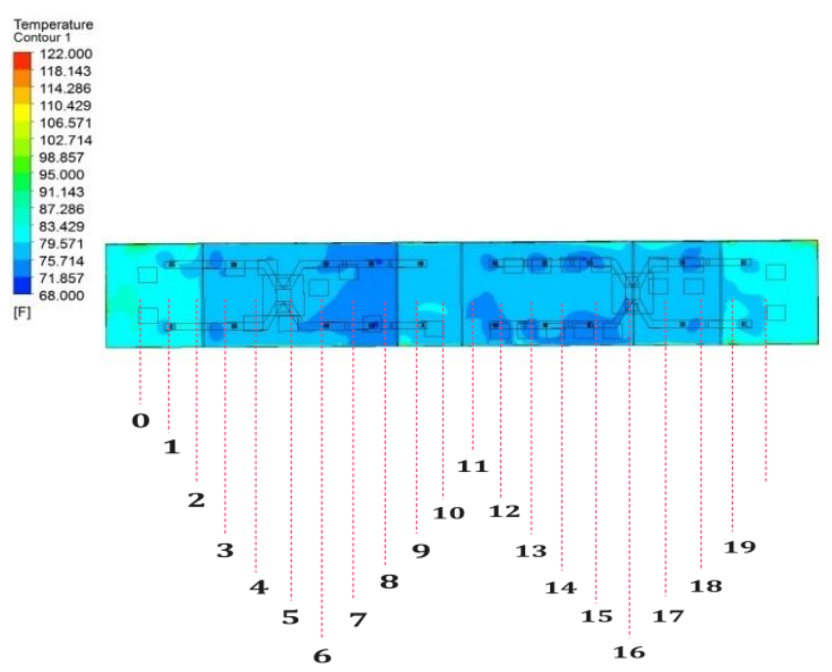

Gambar 7. Kontur distribusi temperatur saluran udara bercabang dengan pengarah 75 derajat

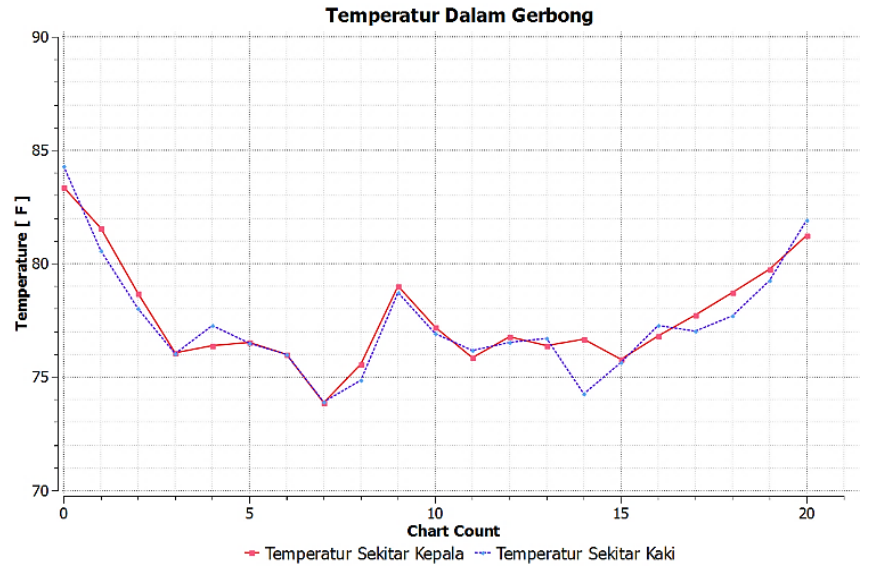

Gambar 8. Grafik Distribusi Temperatur untuk Saluran Udara Bercabang

\section{B. Analisis Psikrometrik}

Kenyamanan termal di dalam kereta Ukur Sulawesi dapat dianalisa dengan menggunakan grafik psikrometrik. Dalam hal ini, parameter yang digunakan ada 3, yakni temperatur bola kering (Tdb), entalpi (h), dan kelembapan relatif (RH). Nilai Tdb didapatkan dari temperatur rata-rata pada Kereta Ukur Sulawesi. Sedangkan nilai RH didapatkan dari perpotongan antara nilai $\mathrm{Tdb}$ dan $\mathrm{h}$.

Tabel 7.

Tingkat Kenyamanan Termal pada Saluran Udara

\begin{tabular}{|c|c|c|c|c|}
\hline \multicolumn{5}{|c|}{ Saluran Udara Lurus } \\
\hline \multirow{2}{*}{ No } & \multirow{2}{*}{\begin{tabular}{c} 
Variasi \\
\cline { 3 - 5 }
\end{tabular}} & Tdd & h & RH \\
\hline 1 & 45 & $F$ & $($ Btu/lb $)$ & $\%$ \\
\hline 2 & 60 & 73,500 & 37,327 & 79,960 \\
\hline 3 & 75 & 75,552 & 34,682 & 77,265 \\
\hline 4 & 90 & 76,533 & 35,166 & 76,700 \\
\hline \multicolumn{5}{|c|}{ Saluran Udara Bercabang } \\
\hline 5 & 45 & 76,685 & 35,208 & 77,325 \\
\hline 6 & 60 & 74,707 & 33,681 & 77,590 \\
\hline 7 & 75 & 77,513 & 36,113 & 78,300 \\
\hline 8 & 90 & 77,305 & 35,800 & 77,690 \\
\hline
\end{tabular}

Berdasarkan hasil analisa psikrometrik yang ditampilkan pada tabel 7, diketahui bahwa variasi sudut pengarah pada lubang udara menyebabkan perubahan temperatur rata-rata di dalam kereta. Kenaikan temperatur rata-rata sebanding dengan kenaikan nilai entalpi. Entalpi merupakan sifat termal dari campuran udara dan uap air yang menunjukkan intensitas kalor dalamudara lembab per satuan massa udara kering di atas suhu acuan.

Analisa kenyamanan termal dilakukan untuk mengetahui tingkat kenyamanan termal yang diterima oleh penumpang. Analisa dilakukan dengan memasukkan nilai temperatur ratarata, entalpi, serta RH dari tabel 7 ke dalam grafik psikrometrik sebagaimana ditunjukkan oleh gambar 9 .

Delapan titik pada gambar 8 mewakili tiap variasi yang dilakukan. Hasilnya menunjukkan bahwa titik 2 (variasi saluran udara lurus dengan pengarah 60 derajat) berada pada daerah sejuk nyaman, sedangkan untuk variasi lainnya termasuk dalam kategori nyaman optimal. 


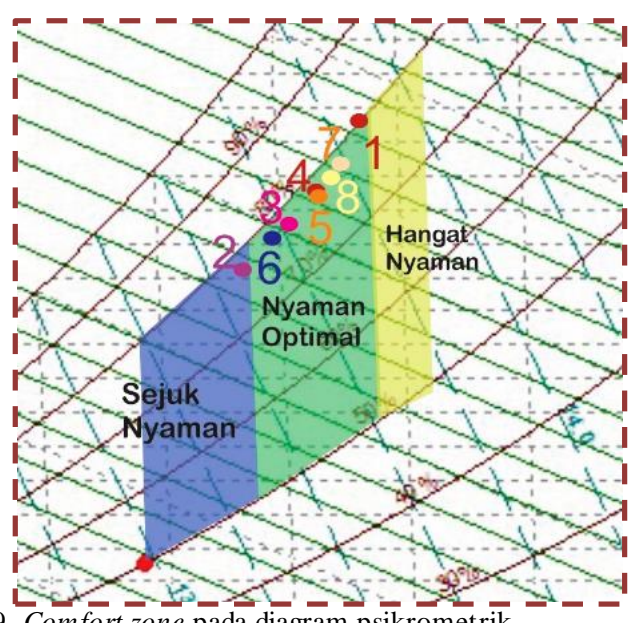

Gambar 9. Comfort zone pada diagram psikrometrik

\section{Analisis Kecepatan Udara di Sekitar Kepala}

Selain faktor kenyamanan termal, kecepatan udara di sekitar kepala juga merupakan salah satu tolok ukur tingkat kenyamanan penumpang menurut SNI 03-6572-2001. Kecepatan udara di sekitar kepala tidak boleh melebihi $0,5 \mathrm{~m} / \mathrm{s}$ atau setara dengan 98,425 fpm. Dari tabel 15 dan 16 didapatkan bahwa variasi yang memenuhi standar tersebut adalah saluran udara bercabang dengan sudut pengarah 75 derajat.

Tabel 8 .

Kecepatan Udara di dalam Kereta Saluran Lurus

\begin{tabular}{|c|c|c|c|c|}
\hline \multirow{3}{*}{$\begin{array}{c}\text { Jarak } \\
f t\end{array}$} & \multicolumn{4}{|c|}{ Kecepatan } \\
\hline & \multicolumn{4}{|c|}{ fpm } \\
\hline & Sudut $45^{\circ}$ & Sudut $60^{\circ}$ & Sudut $75^{\circ}$ & Sudut $90^{\circ}$ \\
\hline 3,287 & 228,149 & 138,189 & 77,165 & 58,071 \\
\hline 10,577 & 106,496 & 129,921 & 266,535 & 45,669 \\
\hline 17,867 & 93,504 & 101,378 & 66,142 & 17,323 \\
\hline 25,157 & 86,023 & 35,827 & 85,433 & 24,213 \\
\hline 32,448 & 237,598 & 41,535 & 46,850 & 39,370 \\
\hline 39,738 & 319,094 & 374,015 & 80,709 & 70,275 \\
\hline 47,028 & 58,464 & 141,929 & 31,496 & 120,079 \\
\hline 54,318 & 56,693 & 38,976 & 34,449 & 45,866 \\
\hline 61,608 & 335,039 & 250,393 & 482,283 & 384,251 \\
\hline 68,898 & 110,630 & 36,614 & 178,149 & 253,149 \\
\hline Rata-rata & 163,169 & 128,878 & 134,921 & 105,827 \\
\hline \multicolumn{5}{|c|}{$\begin{array}{c}\text { Tabel } 9 . \\
\text { Kecepatan Udara di Kereta pada Saluran Bercabang } \\
\end{array}$} \\
\hline \multirow{2}{*}{ Jarak } & \multicolumn{4}{|c|}{ Kecepatan } \\
\hline & \multicolumn{4}{|c|}{ fpm } \\
\hline$f t$ & Sudut $45^{\circ}$ & Sudut $60^{\circ}$ & Sudut $75^{\circ}$ & $\begin{array}{c}\text { Sudut } \\
90^{\circ}\end{array}$ \\
\hline 3,287 & 44,291 & 173,819 & 54,527 & 11,417 \\
\hline 10,577 & 96,653 & 59,055 & 78,346 & 90,748 \\
\hline
\end{tabular}

\begin{tabular}{|c|c|c|c|c|}
\hline 17,867 & 93,701 & 132,480 & 82,677 & 55,512 \\
\hline 25,157 & 49,016 & 160,236 & 88,385 I & 122,638 \\
\hline 32,448 & 55,512 & 107,086 & | & 49,409 \\
\hline 39,738 & 133,858 & 330,314 & 90,354 I & 18,898 \\
\hline 47,028 & 171,260 & 114,764 & | & 48,819 \\
\hline 54,318 & 119,094 & 314,763 & I5,787 & 79,921 \\
\hline 61,608 & 67,913 & 131,890 & I8,818 I & 71,850 \\
\hline 68,898 & 108,071 & 67,913 & | I I I I & 28,150 \\
\hline Rata-rata & 93,937 & 159,232 & 66,810 | & 57,736 \\
\hline
\end{tabular}

\section{KESIMPULAN}

\section{A. Kesimpulan}

Penelitian studi ini adalah membuat desain saluran udara pada Kereta Ukur Sulawesi. Berdasarkan hasil penelitian yang telah dilakukan dapat ditarik kesimpulan sebagai berikut:

- Beban pendinginan untuk Kereta Ukur Sulawesi adalah sebesar 106.166,13 Btu/h atau setara dengan $31,11 \mathrm{~kW}$. Sehingga dipasang 2 buah ACdengan kapasitas masingmasing sebesar $17,5 \mathrm{~kW}$.

- Hasil simulasi CFD menunjukkan bahwa bentuk saluran udara bercabang dengan variasi sudut pengarah outlet 75 derajat paling sesuai untuk diterapkan pada Kereta Ukur Sulawesi. Variasi tersebut menghasilkan temperatur bola kering rata-rata dalam gerbong sebesar $77,51^{\circ} \mathrm{F}$ dengan $\mathrm{RH} 78,3 \%$ dan kecepatan udara rata-rata disekitar udara sebesar 66,81 fpm.

\section{B. Saran}

Beban pendinginan pada kereta dapat berubah-ubah seiring dengan waktu operasi dan rute perjalanan yang dilalui. Sehingga perlu dilakukan pengukuran beban pendinginan secara aktual agar mendapatkan hasil beban pendinginan yang lebih akurat untuk digunakan dalam perancangan sistemsaluran udara.

\section{DAFTAR PUSTAKA}

[1] B. S. Nasional, Konservasi energi sistem tata udara. 2000.

[2] G. Haller, “Thermal Comfort in Rail Vehicles," 2006.

[3] D. J. P. K. P. R. Indonesia, "Spesifikasi Teknis Kereta Ukur Lebar Spoor $1.435 \mathrm{~mm}$," Jakarta, 2015.

[4] A. Bhatia, HVACDucting - Principles and Fundamentals. 2012. [5] ISOVER, HVAC Ducts Handbook. Saint-Gobain Insulation. 2011.

[6] B. S. Nasional, Tata cara perancangan sistem ventilasi dan pengkondisian udara pada bangunan gedung. 2001.

[7] G. Ulfa, L., Hantoro, R., \& Nugroho, “Analisis Temperatur dan Aliran Udara pada Sistem Tata Udara di Gerbong Kereta Api Penumpang Kelas Ekonomi Dengan Variasi Bukaan Jendela," J.Tek. POMITS, 2012.

[8] W. F. Stoecker, Refrigerasi dan Pengkondisian Udara. Jakarta: Erlangga, 1994

[9] P. Satwiko, Fisika Bangunan. Yogyakarta: Andi, 2008.

[10] ASHRAE, Fundamentals Handbook. 1997.

[11] T. H. Ardiyanto, "Perancangan Sistem Tata Udara Kereta Penumpang pada Rangkaian Kereta Api Eksekutif,” 2008. 